Nataliya Holovko, PhD (Pedagogy), Ass. Prof. ORCID iD: 0000-0003-4859-2837,

Svitlana Balashova, PhD (Pedagogy), Ass. Prof. ORCID iD: 0000-0003-2400-867

Taras Shevchenko National University of Kyiv, Kyiv, Ukraine

\title{
HISTORY OF THE DEVELOPMENT OF INCLUSIVE EDUCATION ABROAD
}

The article identifies the features of inclusive education, in particular, describes the content of this education abroad, in countries such as the United States, Italy, Germany. Scientists interpret inclusive education as a comprehensive system of educational services that takes into account the peculiarities of psychophysical development of all students. The forms and methods used in the learning process reveal the individual capabilities and potential of the student. Inclusive educational services cover all aspects of the student's academic and social life and include the formation of an individual curriculum, the creation of a favorable educational environment, the provision of support services of specialists The generalization and systematization of foreign materials allowed us to determine that at the present stage of development of society there is a strengthening of international cooperation between many countries, due to the pedagogical and social significance of inclusion.

Keywords: inclusive education, inclusion, experience, USA, Italy, Germany.

Introduction. An important condition for successful socialization, full participation in society, effective selfrealization and self-development of people with disabilities in various types of professional and social activities is the development of inclusive education. The word "inclusion" comes from the verb "Include" (French origin) and means "contain, include, cover, have in its composition". Nowadays, this word is becoming a term, more reflecting a new view not only of education but also of the place of man in society. Since the 90 s of the twentieth century the leading model of modern social relations in relation to people with disabilities, in particular children with disabilities, is inclusion, which is based on the recognition and respect of individual human differences and provides for the preservation of relative autonomy of each social group. Group, should be modified on the basis of pluralism of customs and opinions [Kolupaeva A., 2014].

Analysis of recent research and publications. Inclusion is the central idea of the development of modern education, which raises profound social and value changes in our society. Inclusion is based on the idea of inclusion, which is that any person (of another race, religion, culture, person with disabilities) can be part of social relations. It is important that this inclusion contributes to the interests of all members of society, increasing their ability to live independently, ensuring the equality of their rights in all activities. Behind this is a deep philosophical problem - the problem of the relationship "I and the Other", the problem of forming our consciousness in terms of social interaction. Openness to others has limits, one of which is to preserve one's identity. In the absence of this possibility, the invasion of another will be perceived as hostile, as destructive, and it will meet resistance.

The studies of the problem of attracting people with special needs to study in educational institutions, their rehabilitation and socialization to social norms were presented by the following scientists: S. Bogdanov, G. Gavryushenko, M. Zakharchuk, A. Kolupaeva, N. Naida, N. Sofiy, I. Sadova, I. Yarmoschuk and others.

The purpose of the article is to consider the features of inclusive education and its development abroad.

Presentation of main positions. Inclusive education as a concept, philosophy of education (such as democratic education, civic education, personality-oriented education etc.) is described differently in different sources. I. Sadova defines that in modern foreign pedagogy there is no generally accepted single interpretation of the term "inclusive education" and there are many approaches to its interpretation: from the narrow sense within a single educational environment in which children interact with people with special needs, teachers and their healthy peers, to a broad understanding of inclusion in the context of philosophy (philosophical category, the main core of which is the recognition of the value of the uniqueness of each child without exception) [Sadova I., 2020].

Inclusive education is a system of educational services based on the principle of ensuring the basic right of a child to education and the right to study at the place of residence in an educational institution. To ensure equal access to quality education, inclusive educational institutions must adapt programs and plans, forms and methods of teaching and resources to the individual needs of children with special educational needs [Bondar V., 2004]. But society itself and its social institutions (education, culture, labor market, etc.) have developed rules governing social interaction. These norms, or social stereotypes, for a long time included the rejection of people with disabilities, their social isolation. Today, disability receives a new interpretation and is seen not as a feature of man, but as a "barrier" of society itself.

Researcher M. Zakharchuk singled out the basic concepts that correspond to the stages of development of inclusive education. (until 1960) - the process of forced separation of persons on racial, social, medical or other grounds. Segregation restricts people's access to education, sets special rules for land use, transport, services and other social benefits. Normalization (1968-1975) - the process of adaptation of a person with special needs to social norms and values necessary for normal life in society. The basic idea of normalization is based on the belief that any person, regardless of the peculiarities of psychophysical development should lead a full social life and receive the necessary support. Educational mainstreaming (1975-1983) is an effective way of educational integration of students with special needs by means of creating a favorable learning environment, socialization, improving curricula, expanding the cognitive abilities of these students in the process of life. Inclusive education (1983-2004) - joint education of people with special needs with peers with typical development; mixed education system (2004 - present) - a comprehensive inclusive education system. The main feature of these stages was the idea of social justice, which opens the way to the realization of the rights and opportunities of each person and provides equal access to quality education [Zakharchuk M., 2013]. 
The idea of inclusion originated at the mainstream stage as a continuation and improvement of the process of integration of children with special needs into the educational space and civil society. Therefore, inclusive education is interpreted as a comprehensive system of educational services that takes into account the peculiarities of psychophysical development of all students. The forms and methods used in the learning process reveal the individual capabilities and potential of the student. Inclusive educational services cover all aspects of the student's academic and social life and include the formation of an individual curriculum, the creation of a favorable educational environment, the provision of support services of specialists. Inclusive education involves the creation of an educational environment that would meet the needs and capabilities of each person, regardless of the peculiarities of his psychophysical development [Lokshina O., 2002]. Inclusive education - a flexible, individualized system of education for children with special needs in psychophysical development in a mass secondary school at the place of residence. Training (if necessary) is based on an individual curriculum, provided with medical, social and psychological and pedagogical support [Kolupaeva A, 2014]. The idea of inclusion arose in the context of large-scale changes in the understanding of human rights, dignity and identity. The change in attitudes towards people with disabilities has been just one manifestation of these changes. The ideology of inclusion (inclusive society) was formed as a result of awareness of the value of human diversity and differences between people.

Today, inclusive education abroad covers the context of the social and legal changes that have taken place in the educational policy of countries where the inclusion of children with special needs has long been a successful and sustainable practice. First of all, as I. Sadova [Sadova I., 2020] points out, inclusive education is considered in the plane of formation of new norms of public morality and respect for differences between people, fight against discrimination and liberal-democratic reforms. Researching inclusive education abroad, O. Prodius points out that in each country inclusive education develops uniquely, depending on the traditions of the educational system, customs and culture, the mentality of the predominant peoples and regulations relating to the education system [Prodius O, 2019].

The introduction of inclusion is possible only on the basis of the principles of democratization and in the absence of discrimination on any grounds. Foreign scholars distinguish three models of inclusive education: conservative, liberal and social-democratic, peculiar to specific developed countries. The conservative system of Italy, Germany, Austria, Belgium and France provides for a high level of stratification by social status and income level. In these countries, inclusive education is provided within the framework of general education, in the absence of integration for people with disabilities. The social democratic regimes of Denmark and Finland solve many of the problems of the so-called "family sphere" (for example, care for the elderly and children). In these countries, inclusive education is successfully provided for all children with disabilities. The liberal regime (UK) is characterized by the dependence of social insurance on the market, with the state regulating the market rather than directly providing direct social security. As the level of social differentiation in society is quite high, social assistance is somewhat limited, given that increasing the level of social benefits reduces the incentive to enter the market and to work. Inclusive education in each country develops uniquely, in accordance with the legal institutions, customs, traditions, mentality of the state. U.S. educational regulations governing the rights and responsibilities of people with disabilities are based on both international and U.S. law. At the national (federal) level, the system of normative and legal provision of equal access to educational services for people with special needs is the US Constitution and other federal legislation in the field of educational and social policy, including laws on the protection of children's civil rights - US Declaration of Independence (1776), US Constitution (1789), Civil Rights Act (1964), Childhood Act (2010); laws governing the educational and legal status of persons with special needs in society.

As early as the middle of the eighteenth century, special education programs were introduced in many shelters and institutions for those people in the United States. Many prominent people of the time, including Samuel Howe and Hervey Wilbur, advocated for the rehabilitation and reintegration of people with disabilities into society. Basically, the philosophy of that period was based on the assumption that diseases such as mental retardation can be cured. In 1830, the first schools for children with visual and hearing problems were established in the United States. Students in these schools were isolated and enrolled in special programs. Because they were large institutions, they were often located hundreds of kilometers from the homes of students and children were here almost all the time [Zakharchuk M.E., 2013]. The first steps towards affordable higher education for people with disabilities were evident after the end of the First World War, especially in the United States. The U.S. government passed the Vocational Rehabilitation Act of 1918, which helps create tuition for disabled veterans in colleges. Also after World War II, a huge number of disabled veterans were enrolled in colleges. Some higher education institutions provided them with a variety of services, such as physical accessibility to university buildings, priority places, and course registration. At that time, discrimination still existed, and some colleges denied students with disabilities due to the unavailability of campuses

In general, the policy of social support for people with disabilities in the United States is based on creating conditions for equal participation of people with disabilities in society. According to the American concept of "social justice", people with special needs are evaluated and perceived not through the prism of special needs, but as citizens with other opportunities. A set of normative and legal documents has been formed in the American educational space, which define a humanistic position on the protection and support of disabled persons. In the modern American school, learning models for students with special needs (adaptive learning environments, integrated classroom, maximization of educational correction, team individualization, cooperative learning, learning based on student achievement) have merged to form a blended learning system that is the dominant model. provision of inclusive educational services. To ensure effective work, inclusive institutions create multidisciplinary teams (secondary school teacher, special school teacher, teacher's assistant, psychologist, social pedagogue, etc.), which work in a joint consultation to provide support, pedagogical and socio-psychological support depending on individual needs of children

Peculiarities of the genesis of inclusive education are thorough legal support of equal rights of persons with special 
needs, coexistence of models of inclusive education of students (adaptive learning environments, integrated classroom, maximization of educational correction, team individualization, cooperative learning, blended learning system, results-based learning student achievements), organization of a differentiated approach to disabled students taking into account their educational needs, integration of educational institutions, research institutions, public organizations in the field of support for people with special needs [Lansdown D., 2001]. Conditions for the effective introduction of inclusive education in the classroom include a combination of clear definition of the purpose and objectives of this process with the flexibility and dynamism of its planning, creating an atmosphere of trust, support, open communication and cooperation of teachers. The organization of inclusive education for children in secondary schools in the United States needs to make changes that will help create an effective inclusive school. In particular, we are talking about changes at the level of the philosophy of inclusion, the formation of an adequate physical environment and quality teaching and methodological support, the creation of new teaching methods (depending on the individual needs of the student) and so on.

Many European documents and projects focusing on inclusive education are covered by the European Agency for Special Needs and Inclusive Education, which aims to help member countries improve their educational policies and practices at all levels of education and lifelong learning. In Western Europe, changes in the special education system began in the 1970 s. Half a century ago in Italy, members of the Democratic Psychiatry movement demanded that most people with mental disabilities be isolated from society and that school reform be introduced to enable children with disabilities to receive education based on inclusive and integrated learning. As a result, Italy completely abandoned special schools. In Italy, the education of children with disabilities in educational schools is guaranteed by the Constitution and Law No. 104 of 1992. And the first law banning the existence of specialized closed classes for children with disabilities was passed in the country in 1971. Italy received an award from the UN for school integration of children with special needs. Today, the European Agency for Special Needs for Education and Inclusive Education recognizes Italy as a leader in the system of inclusive education both in terms of legislation, public funding and tolerance.

Current Italian legislation has contributed to further changes in social attitudes, awareness and maturity of various stakeholders, especially the families of students with disabilities. This has created a kind of virtuous cycle that supports the inclusive potential of the Italian university system. In 1971, under public pressure, a new Law on Education was passed, which legislated the right of parents to choose an educational institution, defined the status of public schools for all children with disabilities, and provided state support for the education of children with mental and physical disabilities. At the initiative of the Democratic Psychiatry public movement, educational reform began in the country in 1972, which enabled children with disabilities to become full members of society. The aim of this public association was to achieve progressive changes in psychiatric medical institutions, to eliminate the isolation of socially dangerous persons with mental disorders who became prisoners in isolated institutions. Members of this movement believed that the emergence of mental disorders in many cases is provoked by society and school, including special educational institutions. Therefore, it is necessary to initiate changes, and, above all, to introduce school reform, which would provide an opportunity to feel like a full member of society and people with mental and physical disabilities. Under public pressure in Italy in 1971 a new "Law on Education" was adopted, which legislated the right of parents to choose an educational institution, defined the status of public schools, where all children with disabilities, provided state support for education of children with mental and physical disabilities development [Kolupaeva A, 2009].

Also, over the last few years, the education system and Italian universities have undergone major changes in order to adapt to European standards and improve the quality of education by personalizing courses. By law, a student with a disability can benefit from the support of a specialist tutor and counselor who provides personal advice throughout the course of study at no cost to the student. The role of a specialized teacher is fundamental as a system mediator, facilitator of communication and moderator with the study group; various roles are realized through focus groups, individual counseling and connecting the student with teachers. The aim of this public association was to achieve progressive changes in psychiatric medical institutions, to eliminate the isolation of socially dangerous persons with mental disorders who became prisoners of isolated institutions. In 1977, amendments were made to the Education Act, which stipulated that children with special needs should go to school near their homes and study in classes with their peers. Class size could not exceed 20 people, no more than two children with disabilities can study in such a class; special classes in mainstream schools are canceled. The updated Education Act of 1992, in the section on the education of children with special needs, prioritizes work on the interaction of schools with institutions of different subordination in order to provide comprehensive assistance to students with special educational needs by various professionals who need to work closely with each other; involvement of parents in the process of teaching children with special needs. Today in the country more than $90 \%$ of children with psychophysical development receive education in general institutions. According to the Education Act, there are no special schools or classes in the Italian school system. Italian law did not formally prohibit such structures. Some of them, more than fifty, still operate mainly in the northern regions. Such institutions are mostly visited by parents of children with very severe cases of complex disability or those who are disappointed with integration education, calling it "compulsory". According to various institutions, specialized schools are attended by several thousand children with disabilities. The education departments of the country's provinces have advisory services, which include various specialists, school administrators, employees of education departments, representatives of public organizations, and, if necessary, specialists from health services. Employees of these services organize inclusive education, diagnosing children and identifying their needs, provide counseling and educational assistance to teachers and school administration. Teachers' assistants work in mass municipal institutions. The didactic and curriculum of the class and the school as a whole is developed in order to involve students with disabilities as widely as possible. In the context of teaching students with disabilities in Italy, it is common to study in inclusive classes subjects traditional for special schools (eg Braille, sign language), provided that they teach students with disabilities who need to study them. 
The education departments of the provinces of the country have advisory services, which include various specialists, school administrators, education departments, representatives of public organizations, and, if necessary, representatives of health services. Employees of these services organize inclusive education, diagnosing children and determining their needs, provide counseling and educational assistance to teachers and school administration. Mass municipal institutions, both preschool and school, employ teacher assistants who provide assistance to students with disabilities and, together with the class teacher, are responsible for the success of students with special needs. Assistants of teachers together with the teacher make individual curricula for each student with features of psychophysical development taking into account his educational needs, including correctional and rehabilitation care, which in some cases is provided outside the school in medical and social rehabilitation centers [Kolupaeva A., 2009]. With the ratification of the UN Convention on the Rights of Persons with Disabilities in Germany in 2009, German secondary schools are obliged to implement inclusive education. Previously, most students with disabilities were educated in so-called "schools with special needs", which were organized according to the types of disability, such as for students with hearing impairments.

The reform of the education sector took place in Germany, where in the early 1970 s, thanks to the activities of the public parent organization Life Assistance, the Ministry of Education, Religion and Culture passed regulations that certify that every child with disabilities has the right to choose an educational institution should be provided with psychological and pedagogical support, involved in the pedagogical process, regardless of the severity of the disease [Kolupaeva A., 2009]. The basic educational document on the organization of joint education of children with developmental disabilities and their healthy peers for all regions of the country (Lands) were adopted in 1972. "Recommendations for the organization of special training". The adopted document provided an opportunity to develop "cooperative" forms of organizing educational activities of mass and special schools, which include joint mass events, separate classes, visiting students with impaired development of mass schools and providing them with correctional and rehabilitation services in a special institution and more. In addressing the issues of psychological and pedagogical support of students with special needs in the context of inclusive education, Germany distinguishes from other European countries the variability of the organization of such support, which is due to differences in the legislation of the Lands. In some countries, educational regulations allow schools to have special teachers and specialists in their staff who provide assistance to children with special needs. In some cases, special teachers perform the functions of a teacher's assistant, working with class teachers. Psychological and pedagogical support is provided by pedagogical centers that operate in each region, although the forms of work organization may be different. The centers provide a variety of assistance to students with special educational needs, conduct career guidance work with them, coordinate the activities of various professionals, advise parents and teachers of mainstream and special schools, and more. In addition to the centers, support for students with special needs is provided by services that operate outside schools and are funded by local governments. These are medical and social services, resource centers, rehabilitation institutions, etc. Currently in Germany, in parallel with the system of special educational institutions, where there are children, mostly with complex disorders, there are institutions of inclusive education [Kolupaeva A., 2009].

$25 \%$ of students with disabilities study in German higher education institutions. By law, such students must be provided with the necessary technical and auxiliary facilities, medical and social support, services from state social services. Parents pay some of the costs only if they receive a higher salary than the average salary. Every child with disabilities has the right to choose a higher education institution, should be provided with psychological and pedagogical support, involved in the pedagogical process, regardless of the severity of the disease. Regarding the issue of psychological and pedagogical support of students with special needs in the context of inclusive education, Germany differs from other European countries in the variability of its organization, due to differences in the legislation of certain regions. In some cities, educational regulations provide for special specialists in educational institutions who provide appropriate assistance. Psychological and pedagogical support is provided by pedagogical centers that operate in each region, although the forms of work organization may be different. In addition to the centers, support for students with special needs is provided by services that operate outside secondary education institutions and are funded by local governments. In each higher education institution there is a network of advisory services or offices, where the student is provided with assistance on all necessary educational and organizational issues. Students with disabilities can also use the services of an assistant during the internship. The establishment of a counseling service office within the university structure is an important step to help students in need. Also, students with special needs are allowed to extend the term of passing tests, replacing the written exam with an oral or passing individually [Prodius O., 2019].

Almost all German universities have specially equipped dormitories for students, but the number of rooms is limited. To ensure equal educational opportunities, the search for ways of joint learning begins, which are conducted in parallel in a number of European countries, the United States and Japan.

Conclusions. Thus, the generalization and systematization of foreign materials allowed to determine that at the present stage of society there is an increase in international cooperation between many countries, due to the pedagogical and social importance of inclusion, which contributes to creating a legal framework for inclusive education and targeted policies. possible discriminatory barriers both in the education system and in society as a whole. Given the importance of these transformations, we conclude that the problem of ensuring the right of children with disabilities to education raises the question of the readiness of secondary schools to implement inclusive education. First of all, it is said that, with the main emphasis on generally accepted legal norms, inclusive education is designed to create a system of value orientations of a developing democratic society, in which the concept of "diversity" is a natural outline. The assessment procedure is the first important step in diagnosing a child's special educational needs. This term is widely used in legislative documents around the world, but the number of types of classification on this basis varies

References

Zakharchuk M. YE. (2013) Stanovlennya ta rozvytok inklyuzyvnoyi osvity u SSHA. Avtoreferat dys. ... kand. ped. nauk 13.00.01 - zahal'na pedahohika ta istoriya pedahohiky .Ternopil', VTS "Vektor", $22 \mathrm{~s}$. 
Kolupayeva A.A. (2009) Inklyuzyvna osvita: realiyi ta perspektyvy: Monohrafiya. Kyyiv. Sammit-Knyha, 272 s.

Kolupayeva A.A. (2014) Inklyuzyvna osvita yak model' sotsial'noho ustroyu. Osoblyva dytyna: navchannya i vykhovannya, № 2, S. 1-12.

Lansdaun D. (2001) Étot myr prynadlezhyt y nam! // Doklad o zhyzny detey ynvalydov dlya spetsyal'noy sessyy Heneral'noy Assambley OON po problemam detey. N'yu-York, sentyabr', $65 \mathrm{~s}$.

Lokshyna O.I.(2002) Kontrol' ta otsinka uspishnosti uchniv u shkolakh Zakhidnoyi Yevropy. Kyyiv: KMPU im. B.D. Hrinchenka, $31 \mathrm{~s}$.

Prodius O.I. (2019) Osoblyvosti modeley inklyuzyvnoyi osvity v krayinakh Yevropy vidpovidno do vymoh suchasnoho suspil'stva. problemy systemnoho pidkhodu v ekonomitsi. Vypusk № 4(72), S. 86-93.
Sadova I. I. (2020) Pedahohika formuvannya tvorchoyi osobystosti u vyshchiy i zahal'noosvitniy shkolakh. №69. T. 1, S. 188-192.

Suchasni tendentsiyi rozvytku spetsial'noyi osvity (ukrayins'ko-kanads'kyy dosvid) : materialy Mizhnar. konf.(2004) / za red. V. I. Bondarya, R. Petryshyna. Kyyiv : Nauk. svit, 200 s.

Chystyakova I. (2018) Providni napryamy rozvytku inklyuzyvnoyi osvity na suchasnomu etapi: dosvid zarubizhnykh krayin. Pedahohichni nauky: teoriya, istoriya, innovatsiyni tekhnolohiyi, № 7(81) S. 59-70.

Надійшла до редколегії 18.05.21

Наталія Головко, канд. пед. наук, доц.

ORCID iD 0000-0003-4859-2837,

Світлана Балашова, канд. пед. наук, доц.

ORCID iD 0000-0003-2400-867

Київський національний університет імені Тараса Шевченка, Київ, Україна

\section{ІСТОРІЯ РОЗВИТКУ ІНКЛЮЗИВНОЇ ОСВІТИ ЗА КОРДОНОМ}

Визначено особливості інклюзивної освіти, зокрема описано ї̈ зміст за кордоом, у таких країнах, як США, Італія Німеччина. Інклюзивну освіту вчені трактують як комплексну систему надання освітніх послуг, що враховує особливості психофізичного розвитку всіх учнів. Форми і методи, які застосовують у процесі навчання, розкривають індивідуальні можливості та потенціал учня. Інклюзивні освітні послуги охоплюють усі аспекти академічного і суспільного життя учня, а також формування індивідуального навчального плану, створення сприятливого освітнього середовища, забезпечення допоміжними послугами та супроводом фахівців. Узагальнення $i$ систематизація зарубіжних матеріалів дозволили визначити, що на сучасному етапі розвитку суспільства спостеріеається посилення міжнародного співробітництва між багатьма країнами світу, обумовлене педагогічною та соціальною значущістю інклюзії.

Ключові слова: інклюзивна освіта, інклюзія, досвід, США, Італія, Німеччина. 